\title{
PIC マイコンを用いた救急車のサイレン音検出に関する研究
}

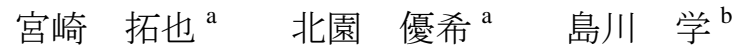 \\ ${ }^{\mathrm{a}}$ 北九州工業高等専門学校 ${ }^{\mathrm{b}}$ 熊本高等専門学校
}

\section{1.はじめに}

緊急車両は交通事故等に駆けつけ救命活動を行う。し かし，緊急車両が一般の車両と事故を起こすこともある。 一般のドライバーのサイレン音の認知の遅れがその一因 として考えられる。この研究はPIC マイコンを用いたサ イレン音検出装置にアルゴリズムを実装することを目的 とする。

サイレン音を検出する研究はいくつか行われている が，その処理には高性能なパソコンが用いられている(1)。 本研究では, PIC 上に実装することでサイレン音検出に 特化した小型で安価な装置を実現することを目的とする。

\section{2. サイレン音検出装置}

この装置は，箱形の本体とそこからケーブルで延びた マイクから成る。本体を車内に置いて，マイクを車外に 設置して使用することを想定している。

本体には入出カインタフェースとして電源スイッチ と押しボタンとブザと液晶画面が備わっている。また， 信号処理マイコンとして dsPIC30F6012A，コーデック IC として SI3000が備わっている。マイクには防風・防雨加 工を施したコンデンサマイクを使用している。駆動電源 として直流 5Vを，DC ケーブルを用いて供給する。Fig. 1 と Fig. 2 にそれぞれ装置本体とマイクの写真を示す。

\section{3. 想定する入力音}

救急車のサイレン音とエンジン音や風切音などの雑 音が混ざった音を想定する。また，救急車と一般の車両 が互いに $100 \mathrm{~km} / \mathrm{h}$ で近づき, ドップラー効果によって周 波数が 1.178 倍まで変化することを想定する。

$$
\text { 4. サイレン音検出アルゴリズム }
$$

4.1 周期性解析アルゴリズム

Fig. 3 にこの周波数解析の流れを示寸。入力として得 られるデータは, マイクが測定した瞬時音圧の值である。

サイレン音には 2 つの音程が含まれるという特徵と， それぞれの音は周期的に断続するという特徴がある。入

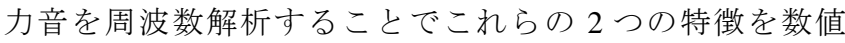

\section{Research of Ambulance Siren Detector}

Takuya Miyazaki ${ }^{\text {a }}$, Yuhki Kitazono ${ }^{\text {a }}$, Manabu Shimakawa ${ }^{\mathrm{b}}$

a Kitakyushu National College of Technology, ${ }^{b}$ Kumamoto National College of Technology

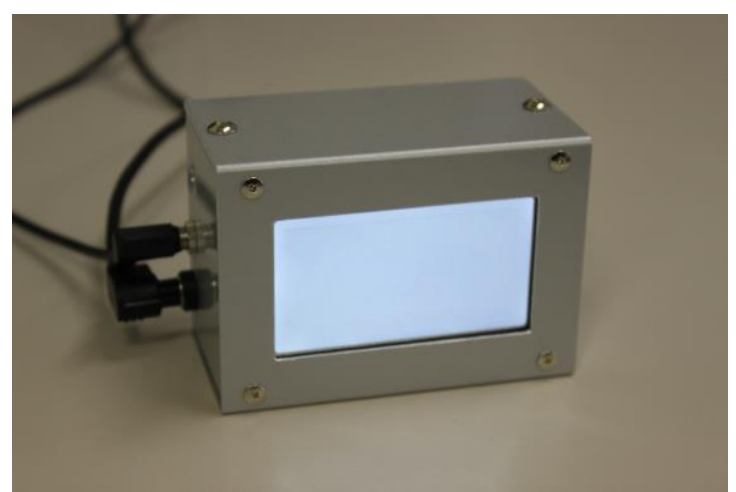

Fig. 1. Appearance of ambulance siren detector.

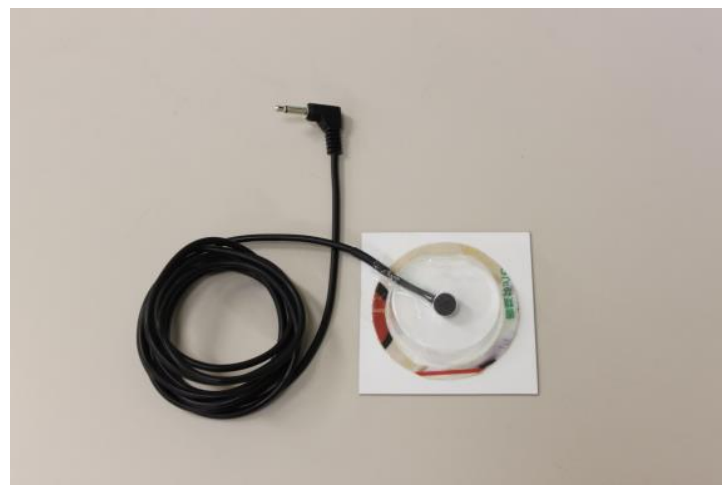

Fig. 2. Appearance of microphone.

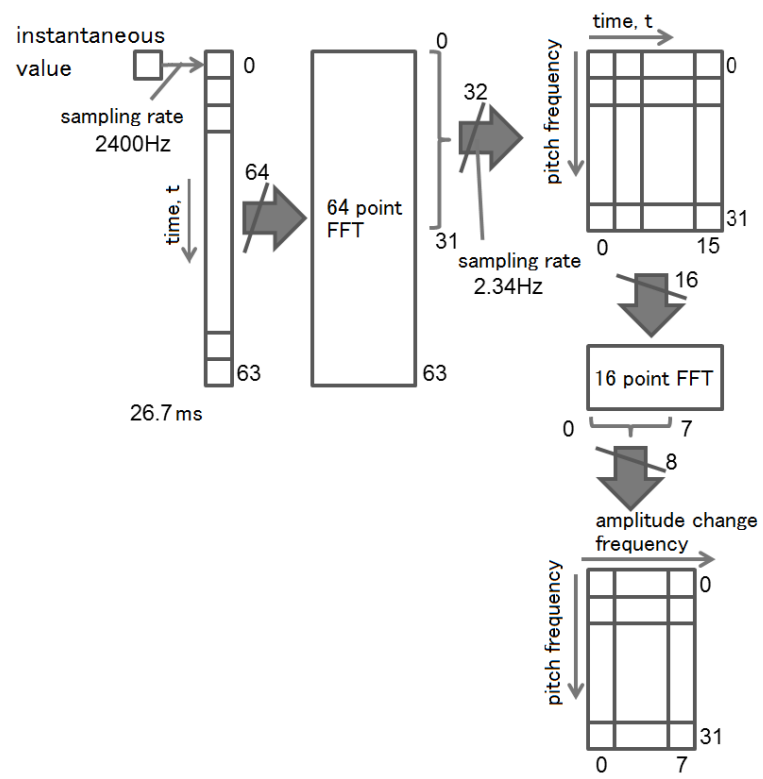

Fig. 3. Flow of analyzing periodicity. 


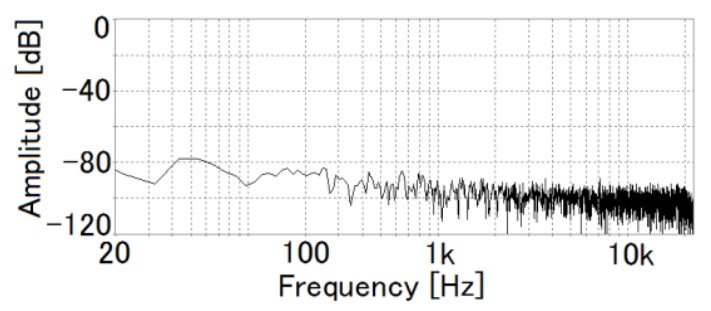

Fig. 4. Spectrum of silent sound.

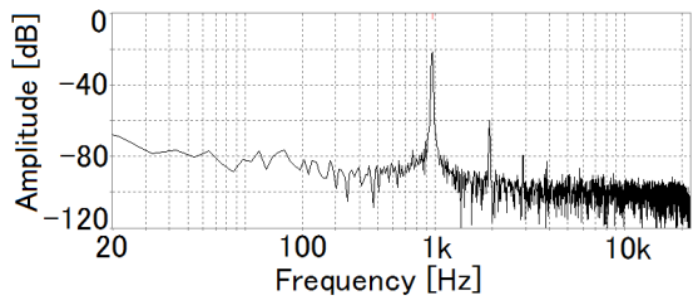

Fig. 5. Spectrum of the siren sound.

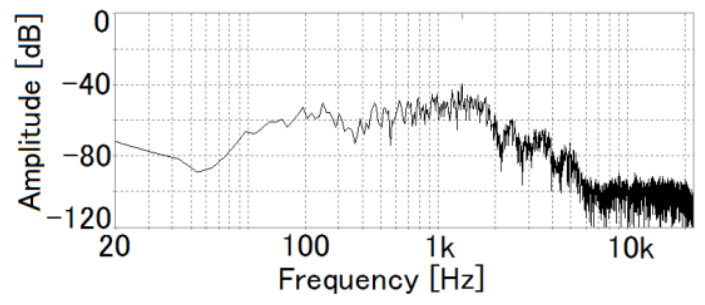

Fig. 6. Spectrum of noise.

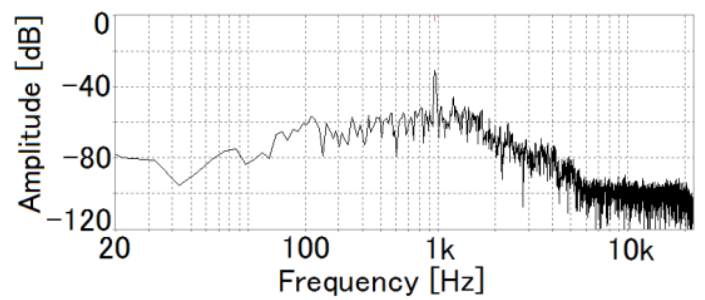

Fig. 7. Spectrum of the sound mixed with the siren and noise.

化することを考えた。

まず，入力された瞬時值から音程を解析するために FFT を用いた。標本周波数 $2,400 \mathrm{~Hz}$ で瞬時值を取得し, 64 点集めた後 FFTを行った。音程 $37.5 \mathrm{~Hz}$ ごとの音の大 きさと位相を得た。

次に, 得られた音程ごとの音の大きさからその断続周 波数を解析するため, もう一段階 FFT を用いた。標本周 波数 $2.34 \mathrm{~Hz}$ で音程ごとの音の大きさを取得し，過去 16 個について毎度 FFT を行った。これをすべての音程につ いて繰り返した。断続周波数 $0.14 \mathrm{~Hz}$ ごとの音の変化幅 の大きさと位相を，それぞれの音程について得た。

4.2 サイレン音判定アルゴリズム

サイレン音は高音と低音を交互に繰り返すという特 徴に注目した。このことから 2 つの断続音の位相差は $\pi$ $\operatorname{rad}$ であるといる。
そこで，サイレン音がドップラー効果によって変化し うる範囲の 2 音の組すべてについて，位相差が $0 \mathrm{rad}$ か らどれだけ遠いかを計算した。最も遠い場合に $\pi \operatorname{rad}$ なる。

計算した值の音程や断続周波数の多少のずれを考慮 して周波数空間で区間平均を求めた。さらに，位相差 $\pi$ $\mathrm{rad}$ が連続していることを調べるためにフィードバック を用いた。こうして得られた值のうちの最大の值を評価 值として用いた。

そして，評価值に閾值を設けて閯值以上ならばサイレ ン音であると判断するとした。ここで用いる閾值は試行 錯誤的に求められたものである。

\section{5. 結果}

サイレン音としてコンピュータで疑似的に生成した もの，雑音として白色雑音を用いて，屋内で実験を行っ た。何も音を入力しない場合，サイレン音を入力した場 合，白色雑音を入力した場合，サイレン音と白色雑音が 混ざった音を入力した場合についてそれぞれ実験を行っ た。それらの音のスペクトルを Fig. 4 から Fig. 7 に示す。 Fig. 4 の場合と Fig. 6 の場合, 装置は反応しなかった。すな わち, サイレン音がないことを判断できたといえる。Fig. 5 と Fig. 7 の場合, 装置は反応した。すなわち, サイレン音を検出でき たといえる。

そして，ドップラー効果を考慮して周波数を 1.178 倍 にした疑似サイレン音で同様の実験を行った。いずれも， サイレン音がある場合にだけ装置は反応した。

サイレン音とホワイトノイズの大きさの組み合わせをさまざま に変えて実験した。その結果, $\mathrm{S} / \mathrm{N}$ 比は $0 \mathrm{~dB}$ 程度まで検出 可能であった。サイレン音の入力から応答までにはおよ そ 8 秒かかった。

\section{6. 今後の課題}

応答までにかかる時間を短縮し，また誤検出を無くす ことが課題である。そのために，フィードバックのフィ ルタを設計することや統計処理を用いることが考えられ る。

また，データメモリの利用効率を上げてより高度な処 理を可能にすることが課題である。

文献

（1）森下諒一, 他：「安全運転支援のための緊急自動車のサイレン音の 検出」，電子情報通信学会技術研究報告 福祉情報工学， Vol. 109, No. 467 , pp. $15-20,2010$ 